\title{
Ethno-Medicinal Survey of Plants Used in Fever and Biological Activity of Selected Medicinal Plants
}

\author{
${ }^{1}$ Sunila Paudel, ${ }^{1}$ Khem Raj Joshi \\ ${ }^{1}$ School of Health and Allied Sciences, Faculty of Health Sciences, Pokhara University, Nepal
}

\begin{abstract}
Fifty one plant species belonging to 35 families were documented for the traditional treatment of fever. The widely used species are Centellaasiatica (50\%), Ocimumsantum (22.5\%), Cissampelospareira (19.5\%), Rubusellipticus (10\%), and Allium hypsistum (14\%). Leaves were used in majority of cases followed by roots in the form of decoction, juice, infusion with or without solvents such as water. Leave extract of R. ellipticus showed potent antioxidant activity towards 1, 1-diphenyl-2-picryl hydrazyl (DPPH) free radical scavenging activity with $1 C_{50}$ value $2.98 \mu \mathrm{g} / \mathrm{ml}$ compared with standard Ascorbic acid $(4.77 \mu \mathrm{g}$ ) $\mathrm{ml)}$. The antibacterial activity of the leave of $R$. ellipticus showed comparable zone of inhibition with that of standard drugs at a concentration of $1 \mathrm{mg} / \mathrm{ml}$.
\end{abstract}

Keywords: Fever, Antioxidant, Antimicrobial activity, Rubusellipticus, Centellaasiatica

Corresponding address: School of Health and Allied Sciences, Faculty of Health Sciences, Pokhara University, Nepal.

E-mail:khemraj_pu@yahoo.com

\section{INTRODUCTION}

Ancient people utilized several parts of plants in different treatment purposes for centuries in maintaining human health and in a number of their daily jobs (e.g. fishing and hunting). ${ }^{1}$ However, plants used in traditional medicines are still not well studied although there is a remarkable progress in synthetic organic chemistry. ${ }^{2}$ Plant materials are important resource to combat serious diseases in the world. The traditional medicinal methods and use of medicinal plants still play a vital role to the basic health needs in developing countries like Nepal. But studies on herbal practices in Nepal have been done but to a very less extent. In western region few studies have been conducted in various periods of time by various researchers. ${ }^{3,4,5,6}$

The rise in body temperature above $99^{\circ} \mathrm{F}$ is called fever. ${ }^{6}$ Fever generally occurs due to infection by virus, bacteria, protozoa and other micro-organisms that produce pyrogens. These pyrogens act on white blood cell (WBC) that in turn produces endogenous toxins, which increases PGE2 triggering hypothalamus to elevate body temperature causing fever. ${ }^{7,6,8}$ Most of the antipyretic drugs are toxic to the hepatic cells, golmeruli, cortex of brain and heart muscles. A natural antipyretic agent with reduced or no toxicity is therefore essential. The demand for herbal medicines is rapidly increasing because they have fewer side effects.

An antioxidant is a chemical that prevents the oxidation of other chemicals. They protect the key cell components by neutralizing the damaging effects of free radicals, which are natural byproducts of cell metabolism. ${ }^{9}$ Antioxidants are involved in the prevention of cellular damage like the common pathway for cancer, aging, and other different diseases.

Due to the unnecessary and unethical use of antibiotics, antibiotic resistance to these organisms is increasing day by day. ${ }^{10}$ Therefore, scientists are focusing on the new antimicrobial agents. Medicinal plants can be the best alternative sources for new products in medicine. Antimicrobial compounds from plants may inhibit the growth of microorganisms by different mechanism than those presently used. ${ }^{2}$

Phenolic and flavanoid compounds are widespread in plant kingdom where they act as antioxidants and free radical scavengers. ${ }^{11}$ Phenolic and flavonoids are secondary metabolites synthesized in plants and have biological properties such as, antioxidant, anti-apoptosis, antiaging, anti-carcinogen, antiviral, anti-inflammation, antiatherosclerosis, cardiovascular protection, improvement of the endothelial function, as well as inhibition of angiogenesis and cell proliferation activity. ${ }^{12,13}$

Thus, this study mainly focused on field survey and biological activity of some selected medicinal plants, which were used traditionally for the treatment of fever. Field visitwas conducted in randomly selected 5 villages of Kaski district. In the study, 51 plant species belonging to 35 families were documented for the treatment of fever.

\section{MATERIALS AND METHODS}

\section{Study area}

Field works were conducted in randomly selected 5 villages (Aarmala, Naudanda, Pumdi-Bhumdi, Ghandruk and Kotre) of Kaski district. A survey using questionnaire, 
oral interview and group discussion was conducted. Participatory approach was used in which different people contributed their knowledge acquired over time on the use of common medicinal plants.

Six medicinal plants were selected on the basis of ethno medicinal survey of plants used in fever for their biological activities. They are:

1. Pogostemonbenghalensis (Rudilo-leaves)

2. Ziziphusmauritiana (Bayer- roots)

3. Cissampelospareira (Chillobatulopaat- leaves)

4. Rubusellipticus (Aiselu- leaves)

5. Psidiumguajava (Aamba- leaves) and

6. Allium hypsistum (Jimbu- leaves).

All the plant materials except $A$. hypsistum were collected during field visit. A. hypsistum was collected from Chusang, Mustang and its botanical identification was done by the Botanist.

\section{Extract Preparation}

To the $5 \mathrm{~g}$ of each shade dried sample, $50 \mathrm{ml}$ of $70 \% \mathrm{MeOH}$ was added and left at room temperature for $24 \mathrm{~h}$ for maceration and then filtered. To the residue, the same process was repeated. Both the filtrate were mixed and concentrated in a rotary evaporator at a temperature of $50^{\circ} \mathrm{C}$. After drying of the extract, they were transferred and kept in vacuum desiccators for complete drying. Each extract's yield value was calculated and kept in air tight container for further use. Extraction yield value was calculated after complete drying of the sample extract. The extract value was different for different plant extract.

\section{Antioxidant activity determination}

\section{1, 1-diphenyl-2-picryl hydrazyl (DPPH) assay}

The DPPH radical scavenging assay has been used widely to evaluate the radical scavenging activity of the different type of antioxidant substances. When the free radical reacts to an antioxidant, its free radical property is lost due to chain breakage and its color changes to light yellow. ${ }^{10}$ The ability of the sample to scavenge DPPH radical was determined from,

Radical scavenging activity $(\%)=\left[\left(\mathrm{A}_{0}-\mathrm{A}_{\mathrm{S}}\right) / \mathrm{A}_{0}\right] \times 100$ Where, $\mathrm{A}_{0}=$ Absorbance of control (DPPH solution without the sample) and $A_{s}=$ Absorbance of sample.

The DPPH free radical scavenging assay was performed according to the method by Devkota et al., (2006)..$^{14}$ The scavenging activity (\%) or \% inhibition was then plotted against concentration and from the graph $\mathrm{IC}_{50}$ (Inhibition concentration 50) value was calculated by linear regression analysis with Microsoft office Excel 2007.

\section{Antibacterial activity determination}

The pure cultures of the bacteria with their antibiotic resistance profiles were obtained from the National Public Health, Laboratory (NPHL) Teku, Kathmandu. One gram-positive bacterium; Staphylococcus aureus and two gram-negative bacteria; Escherichia coli and
Proteus vulgaris were selected for the antibacterial activity determination.

In vitro antimicrobial activity was screened by using Well diffusion method according to Senet al., (2012). ${ }^{15}$ Wells ( $6 \mathrm{~mm}$ diameter and about $2 \mathrm{~cm}$ a part) were made in each plates using sterile micropipette tip $0.1 \%$ inoculums suspension was swabbed uniformly and the inoculums was allowed to dry for $30 \mathrm{~min}$. About $50 \mu 1$ of plant extract was added by micropipette into the wells and allowed to diffuse at room temperature for $2 \mathrm{~h}$. Control experiments comprising inoculums without plant extract were set up. Ofloxacin and cefpodoxime were used as standards.10\% DMSO was used as positive control. Media plates were then incubated at $37^{\circ} \mathrm{C}$ for $24 \mathrm{~h}$ in an incubator. The next day, zones of inhibition was calculated for each treatment.

\section{RESULTS}

In the present study, data on 51 Nepalese medicinal plant species belonging to 35 Families used as antipyretic agents have been documented. Scientific name and family were confirmed from plants and People of Nepal and Medicinal Plants of Nepal. ${ }^{16,17}$ The most widely used plants for fever are presented on Figure 1.The figure indicates that $50 \%$ of the people have knowledge about plant C. asiatica for the treatment. $13 \%$ of the respondents don't have any idea. They directly depend on the clinic and heath post nearby them.

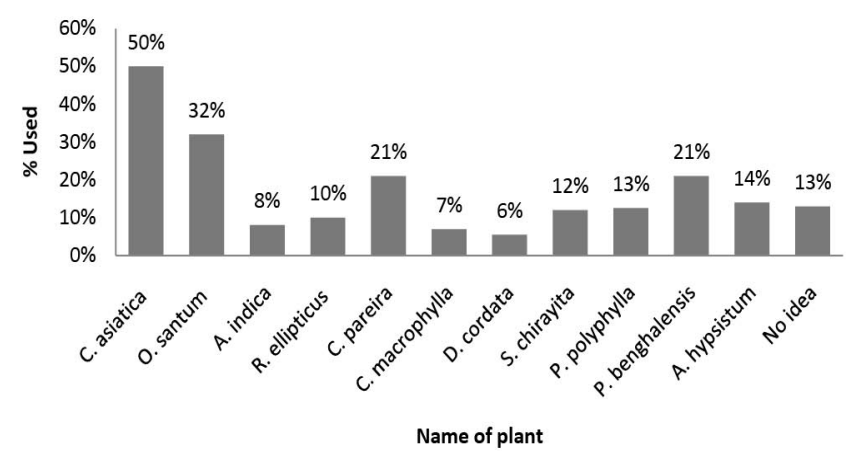

Figure 1: Plants used for fever

The plant parts used for preparation of ingredients; leaves are used in majority of cases followed by roots, fruits, bark, whole plant, rhizome and seed.

In most of the cases ingredients are obtained from multiple plants. According to them single plant for the treatment is not as effective as multiple ingredients. As far as method of processing for crude drug preparation is concerned, majority of the formulations are prepared as crude juice followed by decoction and extraction.

\section{Antioxidant activity determination}

Free radical scavenging activities of different extracts of plant sample were measured by DPPH. Reference standard used was ascorbic acid and experiment was done in triplicate. The methanolic extract of $R$. ellipticus, 
P. guajava and Z. mauritiana plant showed better antioxidant potential when compare to standard ascorbic acid by DPPH scavenging assay method.

$\mathrm{IC}_{50}$ is defined as the amount of antioxidant required to inhibit $50 \%$ of DPPH free radicals under the experimental conditions. Among the studied plant extracts, leaves extract of $R$. ellipticus, Z. mauritiana, P. guajava, exhibited high antioxidant activity in DPPH free radical scavenging assay with $\mathrm{IC}_{50}$ value of $2.98 \mu \mathrm{g} / \mathrm{ml}, 3.94 \mu \mathrm{g} /$ $\mathrm{ml}$ and $4.44 \mu \mathrm{g} / \mathrm{ml}$ respectively less than and equal to that of standard, ascorbic acid $(4.77 \mu \mathrm{g} / \mathrm{ml})$. But extract of A. hypsistum exhibited low antioxidant activity with $\mathrm{IC}_{50}$ value of $127.17 \mu \mathrm{g} / \mathrm{ml}$.

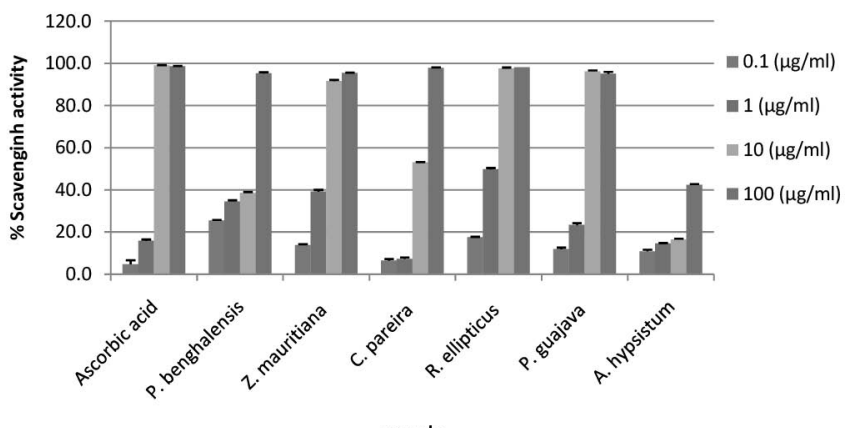

Figure 2: Percentage $\begin{gathered}\text { sample } \\ \text { scavenging of DPPH free }\end{gathered}$ radicals by extracts/ascorbic acid.

Antibacterial activity determination

Different concentrations $(1 \mathrm{mg} / \mathrm{ml}, 3 \mathrm{mg} / \mathrm{ml})$ of plant extract were measured and compared with the zone of inhibitions produced by the standard antibiotics ofloxacin and cefpodoxime.

The methanolic extract of leaves $R$. ellipticusshowed higher activity against both gram positive and gram negative bacteria. At higher concentrations, the extract of P. guajavaand A. hypsistum also showed zone of inhibitions. However, the extract of $A$. hypsistum showed no activity against the Gram-positive bacteria.

\section{Determination of total phenol}

The total phenolic contents in the different extracts ranged from 397 to $81.5 \pm 4.24 \mathrm{mg} \mathrm{GA} / \mathrm{g}$. The highest concentration of phenols was measured in R. ellipticus followed by $P$. guajava. The extract of $C$. pareiraand A. hypsistum extracts contains considerably smaller concentration of phenols.

The total flavonoid contents in the different extracts ranged from $250.5 \pm 2.12$ to $55.5 \pm 4.94 \mathrm{mg} \mathrm{QE} / \mathrm{g}$. The highest concentration of flavonoid was measured in $R$. ellipticus followed by P. benghalensis. Z. mauritianaand A. hypsistum extracts contains considerably smaller concentration of flavonoid.

\section{DISCUSSION}

The uses of medicinal plants for fever by local communities were analyzed. The most preferred species which are still in use are mainly $C$. asiatica $(50 \%)$, O. santum (22.5\%), C. pareira (19.5\%), R. ellipticus (10\%), A. hypsistum (14\%), P. benghalensis (21\%), S. chirayita (12\%), P. polyphylla (13\%), and A. indica $(8 \%)$. Regarding the plant part used, leaves are used in majority of cases followed by roots. Plants are used in the form of decoction, juice, infusion with or without solvents such as water. From the field survey in Terai region of western Nepal different plants like $C$. asiatica, $O$. santum, C. pareira, A. indicaetc are being used for the treatment of fever. ${ }^{6}$ Another study ${ }^{3}$ in Panchase showed the use of different plants like C. asiatica, O. santum, C. pareira, R. ellipticus, S. chirayita, P. polyphylla and A. racemosus for the treatment of fever. These data and the data obtained during the field survey support the use medicinal plants for fever.

Antioxidants like phenols and flavonoids inhibits both cyclooxygenase and lipoxygenase activities, thus diminishes the formation of inflammatory metabolites. Flavonoid also inhibits eicosanoid biosynthesis inhibiting the prostaglandin biosynthesis thus reduces the elevated body temperature causing fever. ${ }^{18,19}$ From our result we can see that plants used for fever possess both phenolic and flavonoids content which also support the use of plants for fever.

The antibacterial activity of a plant extracts depends on the available bioactive compounds, secondary metabolites like tannins, saponin, terpenoids, alkaloids and flavonoids. The result indicates that those plant extract with higher phenolic and flavonoid content show good antibacterial activity. Flavonoids are hydroxylated phenolic substance known to be synthesized by plants in response to microbial infection. Their activity is probably due to their ability to complex with extracellular and soluble proteins and to complex with bacterial cell walls. ${ }^{12}$ Antimicrobial property of saponin is due to its ability to cause leakage of proteins and certain enzymes from the cell. ${ }^{20}$ Tannins have been found to form irreversible complexes with proline rich protein resulting in the inhibition of cell protein synthesis. ${ }^{21}$ The mentioned phytoconstituents are present in the leaves of $R$. ellipticus ${ }^{22}$ which also confirms the highest antibacterial activity among all the selected plants.

Field survey mainly focused to find out the plants that are being used traditionally for the treatment of fever. Field works were conducted in randomly selected 5 villages of Kaski district. Information about medicinal uses of plants was collected by interviewing 200 people from these communities using semi-structured questionnaire. Total of 51 plant species belonging to 35 families have been utilized as a medicine for fever in Kaski district. Among the selected plants, $R$. ellipticus showed potent antioxidant and antimicrobial activity. 


\section{REFERENCES}

1. Chowdhury A, Azam S, Jainul MA, Faruq KO, Islam A. Antibacterial Activities and In Vitro Anti-Inflammatory (Membrane Stability) Properties of Methanolic Extracts of Gardenia coronariaLeaves, International Journal of Microbiology, 2014; 1-5.

2. Bakht J, Ali H, Khan Ali M, Khan A, Saeed M, ShafiM, Islam A, Tayyab M. Antimicrobial Activities of Different Solvents Extracted Samples of Linumusitatissimum by Disc Diffusion Method, African Journal of Biotechnology, 2011;10(85):19825-19835.

3. Chhetri MS, Timilsina YP, Tripathee HP, Devkota KP. Socioecological Status and Antibacterial Activity of Paris polyphyllafrom Panchase Area of Kaski District, Nepal Journal of Science and Technology, 2012;13(2):167-174.

4. Devkota SR.Ethno-medicinally used Anti-inflammatory and Pain relieving Plants in the Kaski District, Western Nepal, World Journal of Pharmaceutical Sciences, 2014; 2(10):1240-1248.

5. Timilsina YP and Tripathee HP. Effect of Applied Treatments on Growth Performance of Thee Cultivated Medicinal Plants of Kaski District, Nepal, Crossing the Border, International Journal of Interdisciplinary Studies, 2014; 2(1):31-40.

6. Singh AG. Medicinal Plants as a Source of Antipyretic Agent in Terai Region of Western Nepal, International Journal of Applied Sciences and Biotechnology, 2013; 1(3):118-126.

7. Jaiswal A, Sutar N, Garai R, Pati MK, Kumar A. Antipyretic Activity of PlatycladusOrieantalis Leaves Extract, International Journal of Applied Biology and Pharmaceutical Technology, 2011; 2(1): 175-178.

8. Chhetri DR. Medicinal Plants Used as Antipyretic Agents by the Traditional Healers of Darjeeling Himalayas, Indian Journal of Traditional knowledge, 2004; 3(3):271-275.

9. Badarinath AV, Mallikarjuna RAK, Chetty CMS, Ramkanth S, Rajan TVS, Gnanaprakash K. A Review on In-vitro Antioxidant Methods, Comparisons, Correlations and Considerations, International Journal of Pharm Tech Research, 2010; 2(2):1276-1285.

10. Mamman, Habila P, Mshelia, Philip W, Susbatrus, Chidama S, Sambo, Wonder K. Antibacterial Effects of Crude Extract of Azadirachtaindicaagainst Escherichia Coli, Salmonella Spp. and Staphylococcus Aureus, International Journal of Medicine and Medical Sciences, 2013; 5(1):14-18.

11. Baba SA and Malik SA. Determination of Total Phenolic and Flavonoid Content, Antimicrobial and Antioxidant Activity of a Roots Extract of ArisaemaJacquemontiiblume, Journal of Taibah University for Science, 2015; 9:449-454.

12. Pal D and Verma P.Flavonoids, a Powerful and Abundant Source of Antioxidants, International Journal of Pharmacy and Pharmaceutical Sciences, 2013; 5(3):95-98.

13. Tamilselvi N, Krishnamoorthy P, Dhamotharan R, Arumugam P, Sagadevan E. Analysis of Total phenols, Total Tannins and Screening of Phytocomponents in Indigoferaaspalathoides, Journal of Chemical and Pharmaceutical Research, 2012; 4(6):3259-3262.

14. Devkota HP, Adhikari A, Paudel S, G.C S, Takano A, Basnet P. Antioxidative Activity of Common Natural Medicines in Nepal, Journal of NPA, 2006; XXIV (1):39-46.

15. Sen A and Batra A. Evaluation of Antimicrobial Activity of Different Solvent Extracts of Medicinal Plant, MeliaAzedarach L., International Journal of Current Pharmaceutical Research, 2012,4(2), 67-73.

16. Manandhar NP. Plants and People of Nepal, Timber Press, Portland, 2002.

17. Adhikari MK, Shakya DM, Kayastha M, Baral SR, Subedi MN. Medicinal Plants of Nepal (Revised), Bulletin of the Department of Plant Resources No.28, Department of Plant Resources, Kathmandu, Nepal, 2007.

18. Agrawal AD. Pharmacological Activities of Flavonoids: a review, InternationalJournal of Pharmaceutical Sciences and nanotechnology, 2011; 4(2):1394-1398.

19. Nijveldt RJ, Nood EV, Hoorn DE, Boelens PG, Norren KV, Leeuwen PA.Flavonoids: a review of probable mechanisms of action and potential applications, The American Journal of Clinical Nutrition, 2001; 74 (4):418-425

20. Shihabudeen MSH, Priscilla HD, Thirumurugan K. Antimicrobial activity and Phytochemical Analysis of Selected Indian Folk Medicinal Plants, International Journal of Pharma Sciences and Research, 2010; 1(10):430-434.

21. Sumathy R, Vijayalakshmi M, Deecaraman M, Sankaranarayanan S, Bama P, Ramachandran J. Screening of Secondary Metabolites, Antioxidant and Antimicrobial Activity from the Petals of Moringaoleifera, World Journal of Pharmacy and Pharmaceutical Sciences, 2014; 3(6):1829-1843.

22. Sharma M, Neerajarani G, Kumar A, Basak D. Evalution of Total Phenolic Content, Antioxidant Properties of Different Leaf Extracts of Rubusellipticus, Ethiopian International Journal of Multidisciplinary Research, 2014; 2(2):14-17. 